\title{
AUSTRAL SEABIRDS: CHALLENGES AND OPPORTUNITIES FOR RESEARCH AND CONSERVATION
}

\author{
by Ben Knight, Henrik Moller, Stuart Bradley and Margaret Davies
}

\begin{abstract}
Knight, B., Moller, H., Bradley, S. \& Davies, M. 2008 (31:xi): Austral seabirds: challenges and opportunities for research and conservation. Papers and Proceedings of the Royal Society of Tasmania 142(1 ): 1-8. https://doi.org/10.26749/rstpp.142.1.1 ISSN $\mathbf{0 0 8 0 - 4 7 0 3 .}$ Centre for the Study of Agriculture, Food and Environment, University of Otago, PO Box 56, Dunedin 9054, New Zealand (BK, $\mathrm{HM}^{*}$ ), Department of Biological Sciences and Biotechnology, Murdoch University, South Street, Murdoch, Western Australia 6150. Australia (SB), Royal Society of Tasmania, GPO Box 1166, Hobart, Tasmania 7001 Australia (MD) * Author for correspondence. Email: henrik.moller@otago.ac.nz

This paper draws together the themes of papers on procellariiform biology contained within this special issue of the Papers and Proceedings of the Royal Society of Tasmania which is a tribute to Irynej Skira. The role of these birds as generalised biomonitors of marine ecosystem health as well as their important interactions with commercial fisheries and human societies are major considerations. Seabird conservation faces challenges from introduced pest species, loss of habitat to urban development, marine pollution and climate and oceanographic changes. Studies are hampered by the difficulties of dealing with birds in remote areas (that are therefore expensive to study), a paucity of funds and problems of overlapping national and international jurisdictions in their individual home ranges or on their migration routes. There is a real need for long-term studies of seabirds because they have delayed breeding systems, a slow rate of reproduction, long life-spans and high adult survival. Such knowledge is important in understanding their population dynamics, the effects of changing climate, the impacts of commercial fishing, pollution, breeding habitat loss and the harvesting of chicks. The value of the long-term studies of Shorttailed Shearwaters, Puffinus tenuirostris, on Fisher Island, Tasmania, is considered in the light of the importance of research investment in basic curiosity-driven research. Neglect of long-term studies and the diminishing role of local scientific journals in the dissemination of baseline data on which to build generalities are the result of changing priorities of government and other funding agencies towards shortterm output-based assessment models. Our present inability to answer the basic question of what determines seabird population abundance and distribution highlights a lack of fundamental population data in Austral seabird research. This must be addressed so that a mixture of comparative, experimental and modelling studies can be mobilised to complement descriptive studies.
\end{abstract}

Key Words: Procellariiformes, seabird ecology, conservation management, research funding, long-term research.

\section{INTRODUCTION}

The research included in this special issue of the Papers and Proceedings of the Royal Society of Tasmania congregates around a central focus on seabirds that breed in coastal regions and outlying islands of Australia (eight papers) and New Zealand (seven papers). This territory is of paramount importance for seabirds globally, with worldwide seabird species density peaking in the north of New Zealand and south of Australia (Chown et al. 1998, Taylor 2000).

Despite the diversity and ecological importance of seabirds in our region, most Austral ornithology has contributed short-term and somewhat fragmentary information from a wide variety of breeding areas. An exception, and one of the longest seabird studies in the Southern Hemisphere, is that of the Short-tailed Shearwater, Puffinus tenuirostris (Temminck, 1835), population on Fisher Island, in Bass Strait. The study was initiated by D.L. (Dom) Serventy of the CSIRO in collaboration with the Tasmanian Wildlife Authority in 1947 to respond to concern about the impact of harvesting levels on this species. Fisher Island was selected because of its small size $(0.8 \mathrm{ha})$, and its accessibility $(250 \mathrm{~m}$ from the local township). This allowed all breeding shearwaters at the colony (two to three hundred) to be marked individually and monitored each year. These logistical benefits undoubtedly played a pivotal role in enabling the study to continue with unchanged protocols over its protracted life span, but came at the price of uncertainty as to how well the Fisher Island populations represented the generalities of the much larger colonies (hundreds of thousands) on other islands. Dom Serventy's reputation as a leading seabird biologist, and his many contacts, established an international web of support for this farsighted project. In the early 1970s Dr Irynej Skira, who had become Serventy's associate in the project, took over the work of banding the shearwaters on Fisher Island and some other of Tasmania's Bass Strait islands. Important contributions followed by Professor Ron Wooller.

The research team was able to gain fundamental knowledge of the species' demography and breeding ecology, including breeding success, site and mate fidelity, and longevity (Ryan 2008). The team's annual population estimates helped determine sustainable harvest of the species and guide indigenous use. Over 33 years while employed by the Tasmanian Government, Dr Skira's commitment and quiet determination resulted in a long-term study on a scale that is rare in the world's seabird research. His work resulted in over 40 scientific papers, technical reports, his doctorate, countless media articles and presentations, and forged links with seabird scientists across the globe (Ryan 2008, Sally Bryant pers. comm.).

This memorial issue pays tribute to Dr Skira's work, and illustrates the current state and continuing scope of seabird research in Australasia. The contributing studies deal with wide-ranging aspects of seabird ecology, including population dynamics (Newman et al. 2008b, Scott et al. 2008), breeding and colonial behaviour (Bancroft 2008, Powell et al. 2008), island biodiversity (Copson \& Brothers 2008, Brothers \& Ledingham 2008, Bancroft et al. 2008), foraging behaviour (Taylor 2008, MacLeod et al. 2008), human impacts (Rosier \& Dyer 2008, Hutton et al. 2008, Waugh et al. 2008), migration (Oka 2008), pest management (Brothers $\&$ Bone 2008), indigenous use and environmentality (Kitson \& Moller 2008, Lyver et al. 2008), and climate change (Brothers \& Bone 2008). The breadth of topics covered by these papers testifies to the diversity of issues that is currently of importance in seabird 
research and the approaches available to confront such issues. However, this wide variation in topics and the inclusion of several valuable foundation descriptive studies hints at the enormous challenge facing Austral seabird research.

This first paper in the collection aims to draw out the crosslinkages between the contributions and poses the question: what next for Austral seabird research? But first we assert the importance of understanding seabirds and consider the conservation threats they face. Given the practical difficulties in studying these wide-ranging and long-lived vertebrates exploiting patchy and variable environments, why should Australian and New Zealand biologists bother with seabird research at all?

\section{THE IMPORTANCE OF AUSTRAL SEABIRD RESEARCH}

Approximately one quarter of the world's seabird species breed in New Zealand and Australian territory (Taylor 2000). Eighty-four seabird species currently breed in New Zealand, of which 35 (42\%) are endemic, breeding nowhere else (Taylor 2000). Australia serves as a breeding ground for 68 seabird species, of which $15(22 \%)$ are endemic (Pizzey \& Knight 2007).

The conservation status of seabirds is diverse and paradoxical; they exhibit a global distribution, population and biomass indicating that they are one of the most successful avian groups (Warham 1996), while at the same time being among the most threatened (Bolton et al. 2004). Almost half (59) of the world's 130 procellariid species, the largest grouping of seabirds, is classified as Critical, Endangered or Vulnerable according to IUCN criteria (IUCN 2007). Forty-seven of the 94 seabird taxa found in New Zealand are currently classified as Vulnerable or worse, with an additional four taxa lacking sufficient data for classification (Taylor 2000). Thirty-seven seabird taxa are so listed in Australia (Environment Australia 2008).

Many seabirds breed in densely populated colonies. Their density and abundance contribute to their role as a "keystone" and "ecosystem engineer" species on many islands, exhibiting wide-ranging effects on species composition, soil nutrification, aeration, and plant regeneration (Payton et al. 2002, Bancoft et al. 2008). The environmental modification caused by burrowing seabirds in particular can have a profound influence on island ecosystems. Wedgetailed Shearwaters, Puffinus pacificus (J.F. Gmelin, 1789), for example, play a fundamental role in determining the species composition of colony associates on Rottnest Island (Bancroft et al. 2008).

As top predators, seabirds afford a unique opportunity for identifying and examining changes at lower trophic levels of the marine ecosystem (Furness \& Camphuysen 1997). Coupled with their wide foraging range and, in some cases, trans-equatorial migration, seabirds are well suited to act as generalised biomonitors of marine ecosystem health. Changes in seabird populations, demographics and breeding characteristics can provide information about climatic and oceanographic changes, as well as marine pollutants (Furness \& Camphuysen 1997). Seabird biomonitoring may also provide valuable information relevant to commercially important fish stocks which serve as prey for many seabird species. However, use of seabirds as biomonitors in this way relies on quantification of the impacts of land-based threats such as harvesting by humans (Kitson \& Moller 2008,
Lyver et al. 2008, Newman et al. 2008 a, b) and artificial mortality impacts at sea like fishing bycatch (Uhlmann $e t$ al. 2005, Waugh et al. 2008) so that background ecosystem effects can be reliably detected.

Commercial fisheries are of enormous economic importance for Australia and New Zealand. Seafood is New Zealand's fifth largest export, earning NZ $\$ 1.25$ billion per year and supporting more than 22000 jobs domestically (Seafood Industry Council 2008) In 2006/7 Australia's seafood exports totalled AUS $\$ 1.49$ billion. The commercial fishing industry is the fifth most valuable Australian rural industry (Australian Department of Foreign Affairs and Trade 2008). Knowledge of the impact of fisheries on seabird populations is crucial for sustainably managing their coexistence. The studies included in this issue by Taylor (2008) and Waugh et al. (2008) examining feeding behaviour, and the extent of fisheries bycatch respectively, are important contributions towards this end.

The close relationship between seabirds and human societies has a long history. Until very recently, the harvest of seabirds and their eggs was an important source of sustenance for coastal human populations in most parts of the world (Moller 2006). Seabird harvests continue to have immense cultural importance for indigenous communities in both New Zealand and Australia (Skira 1995). The ongoing significance of the Grey-faced Petrel, Pterodroma macroptera gouldi (Hutton, 1869), and Sooty Shearwater, Puffinus griseus (J.F. Gmelin, 1789), (collectively known as "Tîtī" or "Muttonbird") harvests for Māori in the North and South Islands of New Zealand is described by the contributions from Kirson \& Moller (2008) and Lyver et al. (2008). An understanding of indigenous environmentality coupled with accurate population and harvest estimation is crucial to assessing and ensuring the sustainability of continuing harvests (Newman et al. 2008b). Maintenance of human cultures and local communities, their traditional lifeways, and Traditional Ecological Knowledge are now recognised as effective components of conservation efforts in Australasia (Wilson et al. 1992, Moller 1996, Skira 1996, New Zealand Conservation Authority 1997) and internationally (BorriniFeyerabend 1996, Posey 1996, IUCN 1997).

\section{SEABIRD CONSERVATION CHALLENGES}

The wide variation in the conservation status of different seabird taxa highlights the importance of measuring population changes to determine appropriate management strategies for each species. Unfortunately many threats potentially contribute to substantial population declines of some Australasian seabirds (Robertson \& Gales 1998). Densely populated breeding colonies are particularly vulnerable to introduced mammalian predators, especially if adult birds are killed (Hamilton \& Moller 1995, Jones 2000). Substantial efforts have been made to eradicate pests from breeding colonies in both New Zealand and Australia, and monitoring the response of seabird populations is of ongoing importance (Brothers \& Bone 2008). Loss of habitat due to expanding urban development is concerning, although, as indicated by Rosier and Dyer's Heron Island study, some seabirds may be able to employ coping strategies to maintain breeding populations (Rosier \& Dyer 2008). Detrimental human impacts on seabirds are also manifested in marine pollution. Hutton et al. (2008) reveal the disturbing extent of plastic ingestion in two shearwater species breeding on 
Lord Howe Island. Falling ocean productivity and climate change impacts are suspected though not proven contributors to seabird decline (Scott et al. 2008).

The wide geographic distribution and long-range migration of seabirds may add difficulties to continuous study, but their philopatric behaviour, typically returning yearly to breeding colonies, makes annual monitoring of many species during the breeding season feasible on a large scale. For decades detailed research of the burrowing petrels was extremely difficult and studies of the behavior of seabirds while foraging and migrating were rudimentary, but this situation has improved with innovations in technology. The advent of data-loggers and telemetry (Shaffer et al. 2006, MacLeod et al. 2008) and use of sophisticated electronic equipment to detect the contents of nesting burrows (Lyver et al. 1998) are just some of the technological advances providing valuable new insights.

A less readily solvable challenge is that many breeding islands are remote, and research is consequently very expensive. It is therefore not surprising that many of the contributions to this special issue of Papers and Proceedings of the Royal Society of Tasmania are descriptive and shortterm in nature. A "descriptive bottleneck" hampers conservation management and research in New World countries like Australia and New Zealand where the biota are comparatively new and unstudied. The population base and funds available for research are limited and there is a high number of threatened species per unit area. The USA spends 76 times more tax revenue per threatened taxon than New Zealand (Perley et al. 2001). As a proxy measure for financial capacity to respond to conservation needs through research and management intervention, this illustrates the severity of the funding deficiency. The Austral predicament is particularly acute for seabirds where much of the research is still focused on first steps - finding out what we have to work with (Bancroft $e$ t al. 2008, Brothers \& Ledingham 2008) followed by rapid and necessarily crude assessment of conservation status (Taylor 2000, Brothers \& Ledingham 2008).

Seabird conservation faces an added challenge from the vast geographic range of many species, roaming over several national and international oceanic jurisdictions. MacLeod et al. (2008) calculate that about $45 \%$ of the home range of Grey-faced Petrels falls in the international High Seas jurisdictional zone, with the remainder split roughly equally within Australian and New Zealand territorial waters. Oka (2008) examined Short-tailed Shearwaters before and after the trans-equatorial migration from Tasmania to the North Pacific and Bering Sea off the coast of Japan, a voyage which crosses numerous national jurisdictions. This wide-ranging journey across political boundaries emphasises a need for co-operation and data sharing to support neighbouring and sometimes distant nations to reach mutually important conservation goals.

\section{THE NEED FOR LONG-TERM STUDIES OF SEABIRDS}

While several papers in this issue advocate more detailed studies on their specific research question (Powell et al. 2008, Taylor 2008), the most prevalent plea is for more long-term foundational monitoring data to becollected (Bancroft 2008, Hutton et al. 2008, Rosier \& Dyer 2008, Scott et al. 2008, Waugh et al. 2008). It is only when these fundamental data are available that more advanced methodologies such as modelling of populations, reproductive success and density dependence can be applied. There is a clear recognition among Australasian researchers that long-term baseline data are gravely needed for large-scale questions to be addressed in seabird ecology, and for anthropogenic and environmental impacts to be properly understood.

The value of long-term studies in ecology is widely understood (e.g., Likens 1989), but the slow population turnover of marine birds, with their delayed breeding, slow rate of reproduction, long life-span and high adult survival rates makes long-term research and population monitoring programs especially pertinent (Wooller et al. 1992, Rosier $\&$ Dyer 2008). Factors affecting seabird populations are highly changeable year to year, with marked variation in reproductive success, chick and adult survival rates (Wooller et al. 1992, Newman et al. 2008 a, b, in press). Rare events, slow processes and subtle and complex phenomena are characteristics of a diverse and variable marine environment that can only be understood by long-term studies based on regular monitoring

Past demographic events can have persistent impacts on population abundance for decades to come, especially when multiple stressors are acting. For example, bycatch of Sooty and Short-tailed shearwaters in Korean and Japanese driftnet fisheries was particularly intense in the $1980 \mathrm{~s}$ and banned in 1991 (Uhlmann et al. 2005). Computer simulations demonstrate that this bycatch has significantly depressed population abundance 15 years after its cessation. This reduction is likely to remain evident for a decade to come, with the length of recovery compounded by El Nino climate oscillations (Newman et al. 2008a). Disentangling the relative importance of different conservation threats that are sporadic and operate at vast distances from breeding colonies is difficult even if long-term and detailed population ecology studies are available. For most seabird species such research simply has not been done.

\section{WHY ARE CONSERVATION AND LONG- TERM STUDIES BEING NEGLECTED?}

There is a severe shortage of funds for research in Australasia generally. Gross Expenditure on Research and Development (GERD) in New Zealand is around $1.2 \%$ compared to an EU-15 average of about $1.8 \%$ and target of 3\% (Adams 2008). Already the United States is spending $2.67 \%$ of GDP on Research \& Development (R\&D), while Japan spends $3.06 \%$. By comparison, Australia spent only 1.62\% of GDP on R\&D in 2002-03 (Australian Vice Chancellors' Committee 2005). In addition, little direct commercial stake in seabird research means that very little industry funding can be accessed by researchers. The high expense associated with research involving remote islands and sophisticated equipment such as telemetry and data-logging makes it particularly difficult to obtain investment in a 15-year lead time in long-term population studies before even basic descriptions of seabird population parameters can be described.

In both New Zealand and Australia, government research funding in recent years has increasingly moved towards output-based assessment measures to guide research investment. This shift towards a more competitive and adversarial funding scheme is likely to have significant consequences for seabird research. It will drive several changes in the nature and scope of research produced by 
our tertiary educational institutions. Some of these changes are likely to be positive, but others may have unintended and unfortunate consequences for seabird research and conservation in particular.

One major consequence of output-based assessment models is the pressure placed on researchers to undertake short-term studies at the expense of good-quality long-term research (Adams 2008). Critics of the British Research Assessment Exercise (RAE) on which the Australian and New Zealand schemes are based argue that the biggest threat is "short termism" (Elton 2000). Elton (2000) specifically warns against other countries following the same path as the United Kingdom, yet New Zealand established a similar system two years later and Australia soon after. A restrictive short-term funding framework that typically has a 3-6 year funding cycle severely hinders the ability of seabird research to answer the large-scale questions that are most important in ecology.

The recent and ongoing publications of research from Fisher Island testify to the value and international rarity of long-term seabird studies. Once databases are established the long-term nature of the information becomes an enormous asset that facilitates research publication - the problem is initiation of the study and its maintenance through the 20-30 years before its long-term quality is reason enough to keep it going. Our main concern is that establishing new studies like that on Fisher Island will be increasingly difficult in the changing political research environment in Australia and New Zealand.

Under the present output-based schemes, research funding is determined in part by the number and "quality" of research publications. Publication in higher-ranked journals leads to more research funding, and because journal rankings are based on readership and citation rate, international journals invariably tend to be ranked more highly than local journals. While international research publication is important, the unfortunate consequence is that local and applied research more suitable for publication in locallyoriented journals is, in effect, financially discouraged. This is particularly negative for seabird research, which is often regionally situated and involves applied conservation and management.

\section{PUBLICATION OF APPLIED RESEARCH: A NEED FOR LOCAL JOURNALS}

Local journals perform an invaluable function in promoting and disseminating research, particularly that which may be region-specific or provide baseline information, exemplified by the papers in this collection. Such studies are extremely valuable for Austral seabird research and management. Local journals enable the publication of locally-grounded, detailed research articles, some of which may be short-term, descriptive, or small-scale in nature. They are also invaluable destinations for taxonomic works requiring fast publication.

Furthermore, publication in local journals has a number of advantages over other journals. The time between submission and publication in such journals is usually much shorter, reaching the audience much sooner. In addition, contributions are typically reviewed by experts with a high level of local knowledge, who can provide detailed constructive feedback. The editors of local journals typically have a more direct interaction with authors, benefiting the final publication.
Despite their valuable roles and benefits, local journals are struggling to survive. Many are published by scientific societies with minimal financial resources, relying heavily on the goodwill of volunteers. We are indebted to Mrs Suzanne Skira and the Tasmanian Department of Primary Industries and Water for their generous grants from which the current issue of Papers and Proceedings of the Royal Society of Tasmania has been funded entirely. This issue will be followed by a second, comprising 12 contributed papers to be published on 28 November 2008, and funded by the Society.

Local journals are vital to accelerate the Austral seabird research past its predominantly descriptive phase and to prevent the unnecessary replication of research that has been left unpublished. We therefore salute the ongoing support of members of the Royal Society of Tasmania, and similar local science organisations, for making regular publications like this one possible.

\section{THE FISHER ISLAND STUDY: PATIENCE, PEOPLE AND RESEARCH POLITICS}

Viewed in the context of increasing challenges to mount long-term seabird studies and publish the results, the value of the Fisher Island Short-tailed Shearwater study and Dr Skira's 25-year commitment to it (Ryan 2008) is outstanding. Why then was the Fisher Island study initiated and what were the key factors that allowed its persistence?

Short-term ecological studies, particularly those funded on the basis of competitive grants, are built around limited and specific key hypotheses. In long-term studies, however, it is often not appropriate to constrain data collection around too limited a set of specific objectives. The significance of the original questions will undoubtedly change throughout the life-time of the study, as new concepts are developed (Bradley et al. 1991). Long-term studies should not be unstructured and must be carefully designed to achieve a balance between data acquired to meet a specific hypothesis and data collected as general information. Cost-effective long-term studies need to allow the testing of retrospective hypotheses, and those undertaking them should be aware of the value of a posteriori data analysis.

Early in the Fisher Island study, Serventy (1957) stated that "The Fisher Island marking program is an aid to the study of all aspects of the natural history of the species". The efficacy of his generalised approach has become clear in hindsight. For example, data from the study have contributed to our understanding of the processes underlying life-time reproductive success (Wooller et al. 1989), the relationship between breeding success and subsequent survival (Bradley et al. 1989), philopatry (the outcome of a translocation experiment begun in the 1960 s with results realised some 20 years later; Serventy et al. 1989), the inter-relationships between breeding success, breeding experience and mate fidelity (Wooller et al. 1990, Bradley et al. 1990, Bradley et al. 1995), the defining characteristics of the restricted number of breeders that contribute to the majority of the succeeding generation (Meathrel et al. 1993), prospecting and recruitment (Bradley et al. 1999), and the implications of breeding birds omitting breeding seasons (Bradley et al. 2000).

The major thrust of all of this work follows closely Dom Serventy's original concept of a fundamental understanding of the population biology of the species, informed through the lens of Life-History Strategy theory. With Dom's retirement, 
the CSIRO wildlife laboratory near Perth involved Dr Ron Wooller, a seabird researcher from Murdoch University, who trained on the kittiwake study of John Coulson, one of the UKs leading long-term seabird studies. Consequently, with Irynej Skira and Ron Wooller in place, the Fisher Island study achieved a transition to a new scientific team, who were able to realise the potential of these data in shaping views of the life-history evolution and population dynamics of long-lived vertebrates.

Fisher Island researchers have always been cognisant of the tension of both how atypical the colony might be considered, and how its logistic convenience makes feasible the types of study outlined above. As a consequence, in 1991 Dr Catherine Meathrel, first involved in the project as a postdoctoral fellow, established a replicate study site on Great Dog Island as a monitoring and experimental site, to add to the information from Fisher Island and to provide some replication (Bradley \& Meathrel 2006).

The Fisher Island research program is ongoing and now in the good leadership hands of Dr Meathrel. It is important that it continues as an inspiration for other teams to establish long-term seabird research programs. The worsening research climate for such studies is worrying at a time when the need for an understanding of global climatic and oceanographic changes and human impacts on biodiversity is becoming ever more critical.

\section{AUSTRAL SEABIRD RESEARCH: WHERE HAVE WE GOT TO AND WHERE DO WE NEED TO GO?}

Given the wide range of challenges facing Austral seabird research and its relative infancy, it is perhaps unsurprising that a pervasive theme running throughout the papers in this issue is an appeal for future research; 11 of the 13 primary research papers in this volume explicitly call for further work to extend and clarify the foundational data reported here.

The advent of sophisticated telemetry and data-loggers now opens the door to understanding seabird behaviour at sea. While we share the excitement of filling in those gaps, in the longer run the critical research remains on understanding long-term population dynamics and what affects numbers. Otherwise we run the risk of locking into another raft of basic descriptive studies of increasing detail without confronting the crucial question for conservation management - what determines seabird population abundance and distribution?

Repeated and systematic monitoring is needed to make the most of the baseline estimates provided in this collection of studies and detect population declines and recolonisations as populations are restored (Brothers \& Bone 2008, Newman et al. 2008b). Challenges remain to make these monitoring programs more accurate. For example, more reliable long-term records of occupancy estimates rather than just breeding burrow entrance density are needed (Scott $e t$ al. 2008). Long-term monitoring of the threats themselves is also needed to complement population monitoring if putative causes for declines or restoration are to be learned. For example, Hutton et al. (2008) call for further studies to assess the long-term trends in plastic ingestion by Fleshfooted Shearwaters on Lord Howe Island. Similarly, Waugh et al. (2008) call for tracking of the evolution of bycatch levels across areas, target fisheries and years, to better focus mitigation efforts to reduce seabird bycatch.
Studies of immigration and emigration are important for seabirds, but present specific difficulties. In procellariiform reproduction, a small portion of fledglings breed away from their natal territory and it is rhese that have a potentially crucial role in metapopulation dynamics and local population regulation (Scott et al. 2008, Newman et al. 2008 a, b). In general, metapopulation connectivity has not been studied amongst seabirds and the emergence of more fine-grained genetic and isotopic study techniques is eagerly awaited to establish global species population assessments - the expense of seabird surveys on remote islands usually precludes complete coverage of the breeding range. For example, rigorous estimates of other Sooty Shearwater populations would be beneficial for establishing whether the declines observed on the Snares by Scott et al. (2008) are occurring at the same rate throughout the species range, including the large and practically unstudied breeding populations in southern Chile and Terra Del Fuego.

Climate change is mentioned by several authors as a threat (Brothers \& Bone 2008, MacLeod et al. 2008, Scott et al. 2008) but so far little direct evidence of its impact on Austral seabirds has been published. We predict this will become increasingly imperative as climate change accelerates (Hennessy et al. 2007) and interacts with existing threats to create synergistic effects from multiple stressors. In view of the importance of the oceans in producing oxygen and absorbing carbon dioxide, marine ecosystem health is paramount for the biosphere and the value of seabirds as biomonitors will be all the more evident.

Future studies must cross-reference behavioural and ecological patterns with spatial and temporal variation in potential conservation threats and spatio-temporal variation in oceanic conditions. This complexity is well illustrated by MacLeod et al. (2008)'s calls for future work to investigate the extent of overlap between the at-sea distribution of Grey-faced Petrels and commercial fisheries activity to determine the risk that this industry poses for this species. Environmental factors influencing the at-sea distribution of Grey-faced Petrels are the key to better understanding of the potential impact of climate change. Without this information, resource managers are unable to assess (1) direct and indirect effects of commercial fisheries, or (2) the effect of oceanic and atmospheric climate on Grey-faced Petrel population dynamics.

The dearth of long-term data sets cripples overarching understanding of patterns and trends in seabird population dynamics. The research in the present volume, in some cases comprising basic species surveys, points to a lack of foundational population data in Austral seabird research. Perhaps unsurprisingly, the current volume does not contain any experimental or manipulative studies, an absence that limits the scope of causal inferences and conclusions that can be drawn. Complete long-term baseline data must be built on by a mixture of comparative, experimental and modelling studies to complement the types of descriptive studies reported here (Hutton et al. 2008). Long-term descriptive monitoring studies form the basis of hypotheses for manipulative and experimental research designs, and can act as an external check on modelling studies (see Moller 2006). Ongoing monitoring can also reveal unexpected trends, generating hypotheses that would not emerge without continuing data collection (Burt 1994). In turn, demographic and population modelling can overcome some of the limitations of monitoring by allowing the prediction of responses to environmental changes. All of 
these approaches require a solid foundation of long-term population and demographic monitoring data. This is where research effort must be focused, and where funding needs to be directed for an integrated and coherent research framework to emerge.

A further potential research avenue for learning how to conserve seabirds is the use of adaptive management. As a practical alternative to field experimentation, adaptive management theoretically offers longer term perturbations on more ecologically realistic spatial and temporal scales (Raffaelli \& Moller 2000). For seabird ecology, this approach is most likely to be useful where management experiments involve removing threats at breeding colonies. Learning from adaptive management requires a BeforeAfter-Control-Impact monitoring design to rigorously detect how a seabird population responds to mitigation of a threat, which in turn depends on standardisation and repeatability of survey methodology. While monitoring may be disparaged by some as simple, low-grade science, the long-term data sets it can produce are a necessity for more complex research methodologies to build on (Burt 1994). Many of the baseline studies reported in this volume will provide valuable benchmarks for future comparisons, just as Scott et al (2008) and Newman et al. (2008a) have been able to use fragmentary historical data to detect major changes in abundance. However, a more structured "active adaptive management" approach (Walters \& Holling 1990) using multiple treatments, reference comparisons and adequate replication will be needed to determine and partition the causes of observed changes. Knowing why change is triggered (or why management intervention failed to trigger the expected gains) is the key to more empowered seabird conservation investments to stem widespread declines of Australia and New Zealand's diverse seabird species and to maintain ecosystem health in our magnificent seabird breeding islands. When coupled with a critical lack of funds for conservation management itself, the comparative lack of published locally-focused research and adaptive management to help prioritise management interventions becomes all the more risky for seabird conservation.

We urge more inclusion of ethno-ornithology to hasten research and guide conservation management. As Lyver et al. (2008) point out, indigenous peoples possess extensive knowledge of both harvested and non-harvested species, and this knowledge can be regionally unique. Indigenous knowledge bases must not be devalued for their regional diversity and specificity. There must be an appropriate outlet for dissemination and its importance should be reflected in funding frameworks. Indigenous perspectives on environmentalism have particular relevance to regional conservation efforts, and the narrow Western-scienceoriented framework on which the Australian and New Zealand funding schemes are based potentially hinders the valuable participation of indigenous peoples in the decisionmaking process of environmental management initiatives.

Despite the immense challenges facing the field of Austral seabird research, progress is certainly being made and obstacles overcome due to the determination and perseverance of researchers. While the current trend towards increasingly contested research funding in Australia and New Zealand threatens progress, potential benefits of a more rigorous research framework may emerge. We must strive to ensure that the long-term studies currently operating continue, and work hard to generate an environment in which new long-term studies can be established. From here, a research framework combining advanced and complementary methodologies can develop and continue to address the crucial overarching questions in seabird ecology in this globally important region.

\section{ACKNOWLEDGEMENTS}

This publication has been a great team effort. Suzanne Skira initiated the project and it snowballed from there. We were gratified and overwhelmed by the generous response of authors to the invitation to contribute to the issue - a fitting tribute to Irynej Skira. Henrik Moller was instrumental in pulling the project together initially. This overarching manuscript is the result of his and Ben Knight's drawing together of all the contributions and dissection of the underlying themes. The production team was headed by the Royal Society of Tasmania's Honorary Editor, Margaret Davies. Caroline Mordaunt was the final copy editor and her eagle eye picked out the missed italics, spaces or references. June Pongratz set the volume, modified illustrations and tables to make them conform to the journal style, or to assist with quality reproduction. Final production is the result of her extensive skills. Theresa Downs commented on an earlier version of this manuscript. We are indebted to the 35 referees of all 18 papers collected here - refereeing is a thankless task but a crucial part of scientific professional service. We thank Mike Brittain for permission to use his spectacular photograph of a humpback whale surfacing amongst Short-tailed Shearwaters in the Bering Sea in 2004.

This special edition of the Papers and Proceedings of the Royal Society of Tasmania has been made possible by generous donations from the Tasmanian Department of Primary Industries and Water through the Secretary Kim Evans and Irynej's wife Suzanne Skira. Their generosity and the overwhelming response from authors, referees and the editorial team reflects the magnitude of Irynej's influence throughout the seabird community, and the gratitude and respect by which he was held by his work colleagues. It has been a way for all of us to say thank you Irynej.

\section{REFERENCES}

Australian Department of Foreign Affairs and Trade 2008: Seafood Industry. www.dfat.gov.au/facts/seafoodindustry. htm (accessed 24 September 2008).

Adams, J. 2008: Strategic Review of the Performance-based Research Fund: The Assessment Process. Report prepared independently for the Tertiary Education Commission.

Australian Vice Chancellors' Committee 2005: Funding Universities - Budgeting for the Future. 2006 AVCC Budget Submission, November 2005: $7 \mathrm{pp}$.

Bancroft, W.J. 2008: Nearest neighbour analysis and spatial relationships of Wedge-tailed Shearwater, Puffinus pacificus (Aves: Procellariiformes) burrow entrances at Radar Reef, Rottnest Island, Western Australia. Papers and Proceedings of the Royal Society of Tasmania 142(1): 31-34.

Bancroft, W.J., Roberts, J.D. \& Garkalis, M.J. 2008: Vertebrate fauna associates of the Wedge-tailed Shearwater, Puffinus pacificus colonies of Rottnest Island: influence of an ecosystem engineer. Papers and Proceedings of the Royal Society of Tasmania 142(1): 21-31.

Bolton, M., Medeiros, R., Hothersall, B., \& Campos, A. 2004: The use of artificial breeding chambers as a conservation 
measure for caviry-nesting procellariiform seabirds: A case study of the Madeiran Storm-Petrel (Oceanodroma castro). Biological Conservation 116: 73-80.

Borrini-Feyerabend, G. 1996: Collaborative Management of Protected Natural Areas: Tailoring the Approach to the Context. Gland, Switzerland: $67 \mathrm{pp}$.

Bradley, J.S., Gunn, B.M., Skira, I.J. \& Wooller, R.D. 1999: Age-dependent prospecting and recruitment to a breeding population of Short-tailed Shearwaters Puffinus tenuirostris. Ibis 141: 277-285.

Bradley, J.S. \& Meathrel C.M. 2006: The prediction of individual reproductive success in Short-tailed Shearwaters Puffinus tenuirostris. In Schodde R (ed.): Proceedings of the 23rd International Ornithological Congress 52 (Suppl. 1): 91-95.

Bradley, J.S., Skira, I.J. \& Wooller, R.D. 1991: A long-term study of Short-tailed Shearwaters Puffinus tenuirostris on Fisher Island, Australia. Ibis 133 (Suppl. 1): 55-61.

Bradley, J.S., Wooller, R.D. \& Skira, I.J. 1995: The relationship of pair-bond formation and duration to reproductive success in the Short-tailed Shearwater Puffinus tenuirostris. Journal of Animal Ecology 64: 31-38.

Bradley, J.S., Wooller, R.D. \& Skira, I.J. 2000: Intermittent breeding in the Short-tailed Shearwater Puffinus tenuirostris. Journal of Animal Ecology 69: 639-650.

Bradley, J.S., Wooller, R.D., Skira, I.J. \& Serventy, D.L. 1989: Age-dependent survival of breeding Short-tailed Shearwaters Puffinus tenuirostris. Journal of Animal Ecology 58: $175-188$.

Bradley, J.S., Wooller, R.D., Skira, I.J. \& Serventy, D.L. 1990: The influence of mate retention and divorce upon reproductive success in Short-tailed Shearwaters Puffinus tenuirostris. Journal of Animal Ecology 59: 487-496.

Brothers, N. \& Bone, C. 2008: The response of burrow-nesting petrels and other vulnerable bird species to vertebrate pest management and climate change on sub-Antarctic Macquarie Island. Papers and Proceedings of the Royal Society of Tasmania 142(1): 123-148.

Brothers, N. \& Ledingham, R. 2008: The avifauna of Bishop and Clerk islets and its relationship to nearby Macquarie Island. Papers and Proceedings of the Royal Society of Tasmania 142(1): 117-122

Burt, T.P. 1994: Long-term study of the natural environment: Perceptive science or mindless monitoring? Progress in Physical Geography 18(4): 475-496.

Chown, S.L., Gaston, K.J. \& Williams, P.H. 1998: Global patterns in species richness of pelagic seabirds: the Procellariiformes. Ecography 21: 342-350.

Copson, G.R. \& Brothers, N.P. 2008: Notes on rare, vagrant and exotic avifauna at Macquarie Island, 1901-2000. Papers and Proceedings of the Royal Society of Tasmania 142(1): $105-116$

Elton, L. 2000: The UK research assessment exercise: Unintended consequences. Higher Education Quarterly 54(3): $274-283$.

Environment Australia 2008: Threatened fauna. www. environment.gov.au/biodiversity/threatened/index.html (accessed 24 September 2008)

Furness, R.W. \& Camphuysen, C.J. 1997: Seabirds as monitors of the marine environment. ICES Journal of Marine Science 54: 726-737.

Hamilton, S.A. \& Moller H. 1995: Can PVA models using computer packages offer useful conservation advice? Sooty Shearwaters in New Zealand as a case study. Biological Conservation 73: 107-117.

Hennessy, K., Fitzharris, B., Bates, B.C., Harvey, N., Howden, S.M., Hughes, L. Salinger, J. \& Warrick, R. 2007: Australia and New Zealand. Climare Change 2007: Impacts, Adaptation and Vulnerability. In Parry, M.L. Canziani, O.F., Palutikof, J.P., van der Linden P.J. \& Hanson, C.E. (eds): Working Group II to the Fourth
Assessment Report of the Intergovernmental Panel on Climate Change, Cambridge Universiry Press, Cambridge, UK: 507-540.

Hutton, I., Carlile, N. \& Priddel, D. 2008: Plastic ingestion by Flesh-footed Shearwaters, Puffinus carneipes, and Wedgetailed Shearwaters, Puffinus pacificus. Papers and Proceedings of the Royal Society of Tasmania 142(1): 67-72.

IUCN (International Union for Conservation of Nature and Natural Resources) 1997: Intercommission Task Force on Indigenous People: Indigenous people and sustainability. International Union for Conservation of Nature, Gland, Switzerland: $364 \mathrm{pp}$

IUCN (International Union for Conservation of Nature and Natural Resources) 2007: IUCN Red List of Threatened Species. http://www.iucnredlist.org/info/tables/table4a (accessed 22 September 2008).

Jones, C. 2000: Sooty Shearwater (Puffinus griseus) breeding colonies on mainland south island, New Zealand: Evidence of decline and predictors of persistence. New Zealand Journal of Zoology 27: 327-334.

Kitson, J.C. \& Moller, H. 2008: Looking after your ground: resource management practice by Rakiura Maori Titi harvesters. Papers and Proceedings of the Royal Society of Tasmania 142(1): 161-176.

Likens, G.E. (ed.) 1989: Long-term Studies in Ecology: Approaches and Alternatives. Springer-Verlag, New York: $214 \mathrm{pp}$.

Lyver, P. O'B., Davis, J., Ngamane, L., Anderson, A. \& Clarkin, I. 2008: Hauraki Maori Matauranga for the conservation and harvest of Titi, Pterodroma macroptera gouldi. Papers and Proceeding of the Royal Society of Tasmania 142(1): 149-160.

MacLeod, C.J., Adams, J. \& Lyver, P. 2008: At-sea distribution of satellite-tracked Grey-faced Petrels, Pterodroma macroptera gouldi, captured on the Ruamaahua (Aldermen) Islands, New Zealand. Papers and Proceedings of the Royal Society of Tasmania 142(1): 73-88.

Meathrel, C.E., Bradley, J.S., Wooller, R.D. \& Skira, I.J. 1993: The effect of parental condition on egg-size and reproductive success in short-tailed shearwaters Puffinus tenuirostris. Oecologia 93: 162-164.

Moller, H. 1996: Customary use of indigenous wildlife - Towards a bicultural approach to conserving New Zealand's biodiversity. In B. McFagen, B. \& Simpson, P. (eds): Biodiversity. Department of Conservation, Wellington: $89-125$.

Moller, H. 2006: Are current harvests of seabirds sustainable? Acta Zoologica Sinica 52 (Suppl. 1): 649-652.

New Zealand Conservation Authority 1997: Mãori Customary Use of Native Birds, Plants and Other Traditional Materials. New Zealand Conservation Authority, Wellington, New Zealand: $178 \mathrm{pp}$.

Newman, J., Clucas, R., Moller, H., Fletcher, D., Bragg, C., Mckechnie, S. \& Scott, D. 2008a: Sustainability of Tìuī harvesting by Rakiura Māori: A synthesis report. University of Otago Wildlife Report: No. 210: 1-118.

Newman, J., Fletcher, D., Moller, H., Harper, G., Bragg, C., Scott, D. \& McKechnie, S. in press: Improved estimates of breeding success for a burrow nesting petrel, the Sooty Shearwater (Puffinus griseus). Wildlife Research

Newman, J., Scott, D., Moller, H. \& Fletcher, D. 2008b: A population and harvest intensity estimate for Sooty Shearwater, Puffinus griseus, on Taukihepa (Big South Cape), New Zealand. Papers and Proceedings of the Royal Society of Tasmania 142(1): 177-184.

Oka, N. 2008: Nutrient reserve difference between young and adult Short-tailed Shearwaters, Puffinus tenuirostris, before and after trans-equatorial migration. Papers and Proceedings of the Royal Society of Tasmania 142(1): 197-204.

Payton, I. J., Fenner, M., \& Lee, W.G. 2002: Keystone species: The concept and its relevance for conservation management in New Zealand. Science for Conservation 203: 1-29. 
Perley, C., Moller, H., Hamilton, W.J., \& Hutcheson, J. 2001: Towards safeguarding New Zealand's agricultural biodiversity: Research gaps, priorities and potential case studies. Ecosystems Consultants Report 23: 230 pp.

Pizzey, G. \& Knight, F. 2007: A Field Guide to the Birds of Australia. 8th Edition. P. Menkhorst (ed.) Harper Collins, Sydney: $580 \mathrm{pp}$.

Posey, D.A. 1996: Traditional Resource Rights. International Instruments for the Protection and Compensation for Indigenous Peoples and Local Communities. IUCN. Gland, Switzerland: $220 \mathrm{pp}$.

Powell, C., Bradley, S. \& Wooller, R. 2008: Is colony attendance by shearwaters influenced by bright moonlight or inclement weather? Papers and Proceedings of the Royal Society of Tasmania 142(1): 35-44.

Raffaelli, D. \& Moller, H. 2000: Manipulative field experiments in animal ecology - do they promise more than they can deliver? Advances in Ecological Research 30: 299-338.

Robertson, G. \& Gales, R. (eds) 1998: Albatross Biology and Conservation. Surrey Beatty \& Sons, Chipping Norton: $300 \mathrm{pp}$.

Rosier, J. \& Dyer, P. 2008: Wedge-tailed Shearwaters, Puffinus pacificus, and development on Heron Island, Great Barrier Reef, Australia. Papers and Proceedings of the Royal Society of Tasmania 142(1): 99-104.

Ryan, L. 2008: Irynej Skira (1950-2005): A scientific life. Papers and Proceedings of the Royal Society of Tasmania 142(1): 9-20.

Scott, D., Scofield, P., Hunter, C. \& Fletcher, D. 2008: Decline of Sooty Shearwaters, Puffinus griseus, on The Snares, New Zealand. Papers and Proceedings of the Royal Society of Tasmania 142(1): 185-196.

Seafood Industry Council 2008: http://www.seafood.co.nz/scbusiness (accessed 24 September 2008)

Serventy, D.L. 1957: The banding programme on Puffinus tenuirostris (Temminck) I. First report. CSIRO Wildlife Research 2: 51-59.

Serventy, D.L., Gunn, B.M., Skira, I.J., Bradley, J.S. \& Wooller, R.D. 1989: Fledgling translocation and philopatry in a seahird. Oecologia 81: 428-429.

Shaffer, S.A., Tremblay, Y., Weimerskirch, H., Scott, D., Thompson, D., Sagar, P., Moller, H., Taylor, G.A., Block, B.A. \& Costa, D.P. 2006: Migratory shearwarers integrate oceanic resources across the Pacific Ocean in an endless summer. Proceedings of the National Academy of Sciences USA 103: 12799-12802.
Skira, I.J. 1995: A mutton-bird in the hand. Natural History 104(8): 24-35.

Skira, I. 1996: Aboriginal people and muttonbirding in Tasmania. In Bomford, M. \& Caughley, J. (eds): Sustainable use of Wildlife by Aboriginal Peoples and Torres Strait Islanders. Australian Government Publishing Service, Canberra: $167-175$.

Taylor, G.A. 2000: Action plan for seabird conservation in New Zealand Part A: Threatened species. Threatened Species Occasional Publication 16: 1-236.

Taylor, G.A. 2008: Maximum dive depths of eight New Zealand Procellariiformes, including Pterodroma species. Papers and Proceedings of the Royal Society of Tasmania 142(1): 89-98.

Uhlmann, S.S., Fletcher, D. \& Moller, H. 2005: Estimating incidental takes of shearwaters in driftnet fisheries: lessons for the conservation of seabirds. Biological Conservation 123: 151-163.

Walters, C.J. \& Holling, C.S. 1990: Large-scale management experiments and learning by doing. Ecology 71: 20602068

Warham, J. 1996: The Behaviour, Population Biology and Physiology of the Petrels. London: Academic Press: 613 pp.

Waugh, S.M., MacKenzie, D.I. \& Fletcher, D. 2008: Seabird bycatch in New Zealand trawl and longline fisheries, 1998-2004. Papers and Proceeding of the Royal Society of Tasmania 142(1): 45-66.

Wilson, G., McNee, A. \& Platts, P. 1992: Wild Animal Resources: Their Use by Aboriginal Communities. Australian Government Publishing Service, Canberra: 122 pp.

Wooller, R. D., Bradley, J. S., \& Croxall, J. P. 1992: Longterm population studies of seabirds. Trends in Ecology \& Evolution 7(4): 111-114.

Wooller, R.D., Bradley, J.S., Serventy, D.L. \& Skira, I.J. 1989: Lifetime reproductive success in the Short-tailed Shearwater Puffinus tenuirostris. In Newton, I. (ed.): Lifetime Reproduction in Birds. Academic Press, London: $405-417$.

Wooller, R.D., Bradley, J.S., Skira, I.J., \& Serventy, D.L. 1990: Reproductive success of Short-tailed Shearwaters Puffinus tenuirostris in relation to their age and breeding experience. Journal of Animal Ecology 59(1): 161-170.

(accepted 7 October 2008) 